\title{
PEMANASAN GLOBAL
}

\section{Vivi Triana *}

\section{Pendahuluan}

Saat ini perubahan iklim merupakan tantangan paling serius yang dihadapi dunia. Semakin banyak terjadi fenomena penyimpangan cuaca seperti badai, angin ribut, hujan deras, serta perubahan musim tanam. Belum lagi ancaman badai tropis, tsunami, banjir, longsor, kekeringan, meningkatnya potensi kebakaran hutan, punahnya berbagai jenis ikan dan rusaknya terumbu karang, serta krisis air bersih, bahkan peningkatan penyebaran penyakit parasitik seperti Malaria dan Demam Berdarah Dengue (DBD), serta terjadi peningkatan insiden alergi, penyakit pernafasan dan radang selaput otak ((encephalitis). Menurut sebagian besar pakar, kejadian ini diakibatkan oleh yang dinamakan pemanasan global (global warming), akibat dari meningkatnya kandungan gas rumah kaca .

Isu pemanasan global ini sedang hangat dibicarakan di dunia, apalagi dengan adanya fenomena musim dingin yang hangat di tahun 2006-2007. Rata-rata temperatur global tahun $20061,2^{\circ} \mathrm{C}$ lebih hangat daripada rata-rata temperatur di abad ke-20. Hasil pengamatan ilmuwan dari berbagai negara yang tergabung dalam Intergovernmental Panel on Climate Change (IPCC) yang menunjukkan bahwa ternyata selama tahun 1990 - 2005 telah terjadi peningkatan suhu merata di seluruh bagian bumi, yaitu antara $0,15-0,3^{\circ} \mathrm{C}$. Hal ini menimbulkan berbagai masalah, antara lain tenggelamnya pulau-pulau kecil akibat naiknya permukaan air laut sebagai dampak dari mencairnya es di Greenland dan Antartika ( \pm 1 meter pertahun). Berdasarkan penelitian para ilmuan yang tergabung dalam Lembaga Survei Antartika (BIA) barubaru ini, lebih dari 1 juta hektar bongkahan es di wilayah bagian barat antartika atau lingkar kutub selatan terancam meleleh atau pecah. Hal ini merupakan indikator kondisi antartika yang berubah cepat, akibat peningkatan suhu bumi. PBB sangat mengkhawatirkan kondisi ini, karena ini merupakan acaman terbesar yang melanda dunia kedepannya.Jika peningkatan suhu itu terus berlanjut, diperkirakan pada tahun 2040 (33 tahun dari sekarang) lapisan es di kutub-kutub bumi akan habis meleleh. Luapan air laut makin lama makin luas, sehingga akhirnya menelan seluruh pulau.
Tanda lain yang tidak luput dari perhatian adalah menghilangnya salju yang dulu menyelimuti beberapa tempat di wilayah Indonesia, seperti salju di puncak Gunung Jayawijaya di Papua. Serta dari hasil studi yang dilakukan ilmuwan di Pusat Pengembangan Kawasan Pesisir dan Laut, Institut Teknologi Bandung (ITB) pada tahun 2007 mengungkapkan bahwa, ternyata permukaan air laut Teluk Jakarta meningkat setinggi $\pm 0,8 \mathrm{~cm}$.

Mengingat pentingnya isu pemanasan global ini bagi dunia, maka pada Kongres Inter Parliamentary Union (IPU) Assembly ke-116 di Nusa Dua, Bali 29 April sampai dengan 4 Mei 2007 memasukkan topik ini dalam sesi Debat Umum dengan dengan tema utama "Global Warming : ten years after Kyoto" ( Pemanasan Global : 10 tahun setelah Kyoto). Isu ini juga merupakan isu utama dalam pembahasan emergency issue-nya.

Oleh sebab itu, patut kita mengenali lebih jauh, apa yang dimaksud dengan pemanasan global dan bagaimana kita di Indonesia menyikapi dan bahkan membantu menanggulanginya.

\section{Pemanasan Global}

Pemanasan global adalah kejadian meningkatnya temperatur rata-rata atmosfer, laut dan daratan Bumi. Peneliti dari Center for International Forestry Research (CIFOR), menjelaskan, bahwa pemanasan global adalah kejadian terperangkapnya radiasi gelombang panjang matahari (gelombang panas atau infra merah), yang dipancarkan ke bumi oleh gas-gas rumah kaca.

Ada enam jenis gas rumah kaca, yaitu Karbondioksida ( $\mathrm{CO}$ ), Metana ( $\mathrm{CH} 4$ ), Nitrous oksida ( $\mathrm{N} 2 \mathrm{O}$ ), Hydroperfluorokarbon ( $\mathrm{HFCs}$ ), Perfluorokarbon ( CFCs ), Sulfur Heksaflorida ( SF6). Gas-gas ini secara alami terdapat di udara (atmosfer). Efek rumah kaca adalah istilah untuk panas yang terperangkap di dalam atmosfer bumi dan tidak bisa menyebar.

Penipisan lapisan ozon juga memperpanas suhu bumi. Karena, makin tipis lapisan-lapisan teratas atmosfer, makin leluasa memancarkan radiasi gelombang pendek matahari (termasuk ultraviolet) memasuki bumi. Selanjutnya radiasi gelombang pendek ini juga berubah menjadi gelombang panjang atau gelombang panas matahari atau

\footnotetext{
* Staf pengajar PSIKM FK Unand
} 
infra merah, sehingga semakin meningkatkan konsentrasi gas rumah kaca.

Lebih jelasnya prosesnya pemanasan gobal ini adalah sebagai berikut :

- Energi yang masuk ke bumi mengalami serangkaian proses

- $25 \%$ energi dipantulkan oleh awan atau partikel lain ke atmosfer

- $25 \%$ diadsorpsi oleh awan

- $\quad 45 \%$ diadsorpsi oleh permukaan bumi

- 5\% lagi dipantulkan kembali oleh permukaan bumi

- Energi yang diadsorpsi oleh awan dan permukaan bumi $(25 \%+45 \%=70 \%)$ dipantulkan kembali dalam bentuk radiasi infra merah atau gelomabang panas matahari

- Namun sebagian besar infra merah yang dipancarkan bumi tertahan oleh awan, gas $\mathrm{CO} 2$ dan gas gas lain (efek rumah kaca), untuk dikembalikan ke permukaan bumi.

Dalam keadaan normal Efek Rumah Kaca alami diperlukan untuk mengurangi perbedaan suhu antara siang dan malam. Namun dengan meningkatnya Gas Rumah Kaca terutama (CO2), akan semakin banyak gelombang panas matahari atau infra merah yang dipantulkan dari permukaan bumi diserap atmosfer sehingga suhu permukaan bumi semakin meningkat.

\section{PENYEBAB PEMANASANGLOBAL}

Planet Bumi telah menghangat juga mendingin berkali-kali selama 4,65 milyar tahun sejarahnya. Pada saat ini, Bumi menghadapi pemanasan yang cepat, para ilmuan beranggapan hal ini disebabkan oleh aktifitas manusia. Indonesia adalah menjadi Negara terbesar ke-3 di dunia setelah Cina sebagai penyumbang gas rumah kaca dari kebakaran hutan dan pembakaran lahan gambut (yang diubah menjadi permukiman atau hutan industri). Belum lagi volusi udara yang ditimbulkan dari asap kendaraan bermotor di kota-kota besar, asap pabrik dari negara-negara industri. Bukan hanya itu, penyebab utama pemanasan ini adalah pembakaran bahan bakar fosil, seperti batu bara, minyak bumi, dan gas alam, yang melepas karbondioksida $\left(\mathrm{CO}^{2}\right)$ dan gas-gas lainnya yang dikenal sebagai gas rumah kaca ke atmosfer, yang menyebabkan Efek Rumah Kaca.

Ketika atmosfer semakin kaya akan gas-gas rumah kaca ini, ia semakin menjadi insolator yang menahan lebih banyak panas dari Matahari yang dipancarkan ke Bumi. Bumi memanas akibat dari sinar matahari yang sudah masuk ke bumi tidak bisa keluar karena gas-gas rumah kaca ini membentuk lapisan di atmosfer yang memantulkan sinar matahari. Hal ini terjadi akibat peningkatan jumlah gas ini melebihi kemampuan tumbuhan dan laut untuk mengadsorpsinya.

Menurut perkiraan, efek rumah kaca telah meningkatkan suhu bumi rata-rata $1-5^{\circ} \mathrm{C}$. Bila kecenderungan peningkatan gas rumah kaca tetap seperti sekarang akan menyebabkan peningkatan pemanasan global antara $1,5-4,5^{\circ} \mathrm{C}$ sekitar tahun 2030. Dengan meningkatnya konsentrasi gas $\mathrm{CO}_{2}$ di atmosfer, maka akan semakin banyak gelombang panas yang dipantulkan dari permukaan bumi diserap atmosfer. Hal ini akan mengakibatkan suhu permukaan bumi menjadi meningkat.

\section{Gambar:}

Mekanisme terjadinya efek rumah kaca

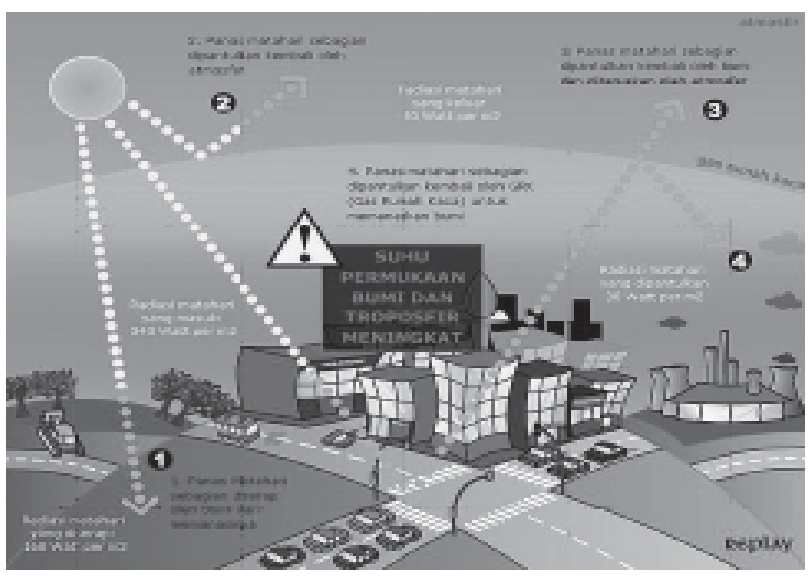

Sumber: Situs kementrian lingkungan hidup

Bumi secara konstan menerima energi, kebanyakan dari sinar matahari tetapi sebagian juga diperoleh dari bumi itu sendiri, yakni melalui energi yang dibebaskan dari proses radioaktif (Holum, 1998:237). Sinar tampak dan sinar ultraviolet yang dipancarkan dari matahari. Radiasi sinar tersebut sebagian dipantulkan oleh atmosfer dan sebagian sampai di permukaan bumi. Di permukaan bumi sebagian radiasi sinar tersebut ada yang dipantulkan dan ada yang diserap oleh permukaan bumi dan menghangatkannya.

\section{Dampak Pemanasan Global}

Para ilmuan menggunakan model komputer dari temperatur, pola presipitasi, dan sirkulasi telah membuat beberapa perkiraan mengenai dampak pemanasan global terhadap cuaca, tinggi permukaan air laut, pantai, pertanian, kehidupan hewan liar dan kesehatan manusia. Dijelaskan sebagai berikut :

\section{Cuaca}

Gejala yang sangat jelas dari pemanasan global adalah berubahnya iklim, contohnya, hujan deras masih sering datang, meski kini kita sudah memasuki bulan yang seharusnya sudah terhitung musim kemarau. Salah satu contoh di Indonesia, misalnya kejadian banjir besar pada bulan Februari 2007 lalu yang merendam lebih dari separuh DKI Jakarta. Menurut perkiraan, dalam 30 tahun terakhir ini, pergantian musim kemarau ke musim hujan terus bergeser. Musim tanam akan lebih panjang di beberapa area. Temperatur pada musim dingin dan malam hari akan cenderung untuk meningkat.

Daerah hangat akan menjadi lebih lembab karena lebih banyak air yang menguap dari lautan. Kelembaban yang tinggi akan meningkatkan curah hujan, secara ratarata, sekitar 1 persen untuk setiap derajat Fahrenheit 
pemanasan. Badai akan menjadi lebih sering. Selain itu air akan lebih cepat menguap dari tanah. Akibatnya beberapa daerah akan menjadi lebih kering dari sebelumnya. Angin akan bertiup lebih kencang dan mungkin dengan pola yang berbeda. Topan badai (hurricane) yang memperoleh kekuatannya dari penguapan air, akan menjadi lebih besar. Berlawanan dengan pemanasan yang terjadi, beberapa periode yang sangat dingin mungkin akan terjadi. Pola cuaca menjadi tidak terprediksi dan lebih ekstrim.Saat sekarang terutama 2-3 tahun ke belakang sangat sulit untuk memprediksi cuaca.

\section{Tinggi Permukaan Laut}

Ketika atmosfer menghangat, daerah bagian Utara dari belahan Bumi Utara (Northern Hemisphere) akan memanas lebih dari daerah-daerah lain di Bumi dan lapisan permukaan lautan juga akan menghangat, akibatnya gunung-gunung es di kutub terutama sekitar Greenland akan mencair. Berdasarkan penelitian para ilmuan yang tergabung dalam Lembaga Survei Antartika (BIA) barubaru ini, lebih dari 1 juta hektar bongkahan es di wilayah bagian barat antartika atau lingkar kutub selatan terancam meleleh atau pecah.

Tinggi permukaan laut di seluruh dunia telah meningkat 10 - $25 \mathrm{~cm}$ (4 - 10 inchi) selama abad ke-20, dan para ilmuan IPCC memprediksi peningkatan lebih lanjut 9 $88 \mathrm{~cm}$ (4 - 35 inchi) pada abad ke-21. Perubahan tinggi ratarata permuka laut ini diukur dari daerah dengan lingkungan yang stabil secara geologi.

\section{Grafik. Perubahan Permukaan Air laut}

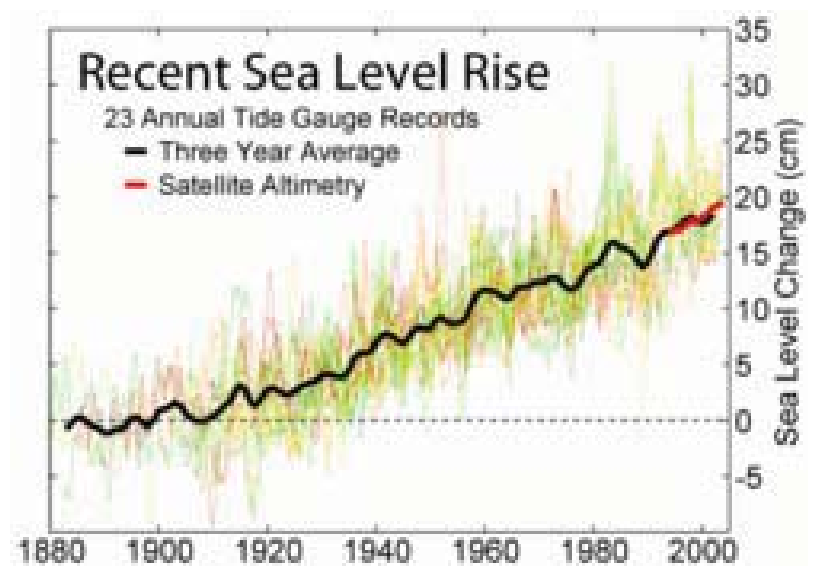

Kenaikan muka air laut secara umum akan mengakibatkan dampak sebagai berikut :

1. Meningkatnya frekuensi dan intensitas banjir

2. Perubahan arus laut dan meluasnya kerusakan manggove (hutan bakau)

3. Meluasnya intrusi air laut

4. Ancaman terhadap kegiatan sosial-ekonomi masyarakat pesisir

5. Berkurangnya luas daratan atau hilangnya pulau-pulau kecil

\section{Pertanian}

Orang mungkin beranggapan bahwa Bumi yang hangat akan menghasilkan lebih banyak makanan dari sebelumnya, tetapi hal ini sebenarnya tidak sama di beberapa tempat. Bagian Selatan Kanada sebagai contoh, mungkin akan mendapat keuntungan dari lebih tingginya curah hujan dan lebih lamanya masa tanam. Di lain pihak, lahan pertanian tropis semi kering di beberapa bagian Afrika mungkin tidak dapat tumbuh. Daerah pertanian gurun yang menggunakan air irigasi dari gunung-gunung yang jauh dapat menderita jika snowpack (kumpulan salju) musim dingin, yang berfungsi sebagai reservoir alami, akan mencair sebelum puncak bulan-bulan masa tanam. Seperti kita ketahui para petani memakai cuaca sebagai patokan penanaman mereka, jadi jika salah prediksi cuaca para petani bisa tidak panen atau hasil panennya tidak bagus sehingga akan mengalami kerugian.

\section{Hewan dan tumbuhan}

Hewan dan tumbuhan menjadi makhluk hidup yang sulit menghindar dari efek pemanasan ini karena sebagian besar lahan telah dikuasai manusia. Dalam pemanasan global, hewan cenderung untuk bermigrasi ke arah kutub atau ke atas pegunungan. Akan tetapi, pembangunan manusia akan menghalangi perpindahan ini. Spesies-spesies yang bermigrasi ke utara atau selatan yang terhalangi oleh kota-kota atau lahan-lahan pertanian mungkin akan mati. Beberapa tipe spesies yang tidak mampu secara cepat berpindah menuju kutub mungkin juga akan musnah. Sedangkan tumbuhan akan mengubah arah pertumbuhannya, mencari daerah baru karena habitat lamanya menjadi terlalu hangat.

\section{Kesehatan manusia}

Wabah penyakit yang biasa ditemukan di daerah tropis, seperti penyakit yang diakibatkan nyamuk dan hewan pembawa penyakit lainnya, akan semakin meluas karena mereka dapat berpindah ke daerah yang sebelumnya terlalu dingin bagi mereka. Anopheles misalnya adalah jenis nyamuk vektor utama penyakit malaria yang selama ini dianggap hanya mampu berkembang biak pada daerahdaerah tropis saja dengan suhu tidak kurang dari 16 derajat celcius dan pada ketinggian kurang dari 1000 m. Namun laporan terakhir menunjukkan nyamuk ini telah ditemukan juga di daerah-daerah subtropis dan pada ketinggian yang sebelumnya tidak ditemukan anopheles seperti di Afrika Tengah dan Ethiopia. Saat ini $45 \%$ penduduk dunia tinggal di daerah di mana mereka dapat tergigit oleh nyamuk pembawa parasit. Persentase ini akan meningkat menjadi $60 \%$ jika temperature meningkat.

Perubahan temperatur, kelembaban udara, dan curah hujan yang ekstrem mengakibatkan nyamuk lebih sering bertelur sehingga vektor yang tertularkan penyakit pun bertambah. Penyakit-penyakit tropis lainnya yang dapat menyebar melalui nyamuk ini yatu seperti Malaria, Demam Berdarah Dengue (DBD), demam kuning, dan cikungunya. 
Guru Besar Tetap Ilmu Parasitologi Fakultas Kedokteran Universitas Padjadjaran (UNPAD), Ridad Agoes mengungkapkan :

\begin{abstract}
"Pemanasan global mengakibatkan arbovirus seperti dengue dan parasit protozoa seperti malaria sudah menyebar ke daerah-daerah yang sebelumnya tidak ada, nyamuk yang menjadi vektor tersebut mampu untuk berkembang biak di daerah yang sebelumnya dianggap terlalu dingin untuk mampu bertahan dan mengakibatkan siklus perkawinan dan pertumbuhan nyamuk dari telur menjadi larva dan nyamuk dewasa lebih singkat, sehingga jumlah populasinya akan cepat sekali naik, saat ini setidaknya 270 juta penduduk dunia menderita malaria dan lebih dari 2 miliar atau $42 \%$ penduduk bumi memiliki risiko terkena malari."
\end{abstract}

Fenomena pemanasan global yang berpengaruh terhadap keganasan penyakit. Para ilmuan juga memprediksi meningkatnya insiden alergi, penyakit pernafasan dan radang selaput otak ((encephalitis), karena udara yang lebih hangat akan memperbanyak polutan, spora mold dan serbuk sari. Akibat Pemanasan Global yang berdampak pada bencana alam seperti banjir juga akan memicu masalah kesehatan masyarakat lain, termasuk juga jenis penyakit lainnya seperti Diare, Leptospirosis, Asma, Kanker Kulit dan Penyakit Paru Obstruktif Kronis (COPD).

\section{Bagaimana Dunia dan Indonesia Menyikapinya}

Isu pemanasan global ini bukanlah isu baru bagi dunia, dimana gagasan dan program menurunkan emisi secara internasional telah dilakukan sejak tahun 1979 dalam bentuk perjanjian internasional, yaitu United Nation Framework Convention on Climate Change ( UNFCC )/ Konvensi Kerangka Kerja PBB Tentang Perubahan Iklim atau lazim disebut Konvensi Perubahan Iklim. Konvensi ini disahkan di Rio de Janeiro pada 14 Mei 1992 sebagai salah satu komitmen dalam KTT Bumi, dan mulai berlaku 21 Maret 1994.

Pemerintah Indonesia mengesahkannya melalui UU no 6 tahun 1994. Melalui konvensi ini Negara Annex 1 ( negara negara industri termasuk Rusia dan Negara Eropa Timur lain yang ekonominya berada dalam transisi menuju ekonomi bebas ) diminta untuk melakukan upaya pengurangan terhadap emisi gas rumah kaca melalui pengembangan program nasional serta inventarisasi gas rumah kaca.

Desember 1997, dari hasil COP 3 ( Conference of Parties ) / Konferensi Negara Pihak ke-3, di Kyoto, Jepang, Protokol Kyoto disahkan sebagai dasar bagi Negara Annex 1 untuk mengurangi emisi gas rumah kaca minimal 5,2\% dari tingkat emisi tahun 1990 menjelang komitmen periode pertama tahun 2008-2012. Target penurunan emisi ini disebut Quantified Emission Limitation and Reduction Objectives ( QELROs) dan diatur pada Annex B Protokol
Kyoto. Indonesia sudah meratifikasi Protokol Kyoto tanggal 28 Juli 2004 melalui UU no 17/2004. Sampai sekarang Amerika Serikat yang menjadi Negara penghasil terbesar gas rumah kaca ( $25 \%$ dari keseluruhan GRK ) dan Australia menolak meratifikasi protokol ini. Amerika menolak dengan alasan bahwa pengurangan penggunaan bahan bakar fosil dan menggantinya dengan gas akan memberi dampak negatif bagi perekonomiannya.

Protokol Kyoto mulai berlaku efektif pada tahun 2005 setelah Rusia meratifikasinya tahun 2004. Ada tiga mekanisme pemenuhan komitmen Negara Annex 1 untuk menurunkan target emisinya, yaitu melalui Joint Implementation ( JI ) / Implementasi Bersama, Emission Trading ( ET ) / Perdagangan Emisi atau sering disebut sebagai Perdagangan Karbon dan Clean Development Program ( CDM ) / Mekanisme Pembangunan Bersih (MPB).

Kemudian pada Kongres Inter Parliamentary Union (IPU) Assembly ke-116 di Nusa Dua, Bali 29 April sampai dengan 4 Mei 2007 memasukkan topik ini dalam sesi Debat Umum dengan dengan tema utama "Global Warming : ten years after Kyoto" ( Pemanasan Global : 10 tahun setelah Kyoto). Isu ini juga merupakan isu utama dalam pembahasan emergency issue-nya. Pada tahun 2007 itu Bali merehabilitasi 250 hektar dari total 4.000 hektar hutan mangrovenya di lima wilayah yaitu Denpasar, Kabupaten Badung, Jembrana, Buleleng dan Klungkung, dengan bantuan Japan International Cooperation Agency (JICA). Upaya ini dilakukan untuk mengantisipasi tsunami mengingat mangrove sangat efektif meredam tsunami. Ini merupakan upaya konkrit dalam mengurangi dampak pemanasan global yang dapat pula menyebabkan tsunami. Penerapan Tri Hita Karana sebagai wujud peran masyarakat dalam melestarikan alamnya. Konsep Tri Hita Karana• (Hubungan harmonis antar manusia dengan Tuhan, Manusia dengan sesamanya dan Manusia dengan alam lingkungannya) yang mengacu pada akar budaya Bali dapat menjadi acuan di dalam mengatasi masalah perusakan lingkungan yang menjadi penyebab pemanasan global dewasa ini.

Pada skala kecil masyarakat dapat berpartisipasi dalam mengurangi akibatnya, antara lain dengan :

1. Menghemat pemakaian air

2. Mengurangi penggunaan kendaraan pribadi

3. Menggunakan bahan pembersih, sabun yang aman bagi lingkungan.

4. Mengurangi pembakaran bahan yang tak dapat didaur ulang

5. Menghijaukan lingkungan sekitar dengan penanaman pohon

6. Memperhatikan kebersihan lingkungan sekitar

7. Membuat kompos

8. Mendorong usaha kerajinan dengan bahan sisa yang bisa didaur ulang

9. Menggunakan lampu hemat energi 


\section{Penutup}

Pemanasan global (global warming) pada dasarnya merupakan fenomena peningkatan temperatur global dari tahun ke tahun karena terjadinya efek rumah kaca (greenhouse effect) yang disebabkan oleh meningkatnya emisi gas-gas seperti karbondioksida (CO2), metana (CH4), dinitrooksida (N2O) dan CFC sehingga energi matahari terperangkap dalam atmosfer bumi. Berbagai literatur menunjukkan kenaikan temperatur global termasuk Indonesia yang terjadi pada kisaran $1,5-40{ }^{\circ} \mathrm{C}$ pada akhir abad 21.

Pemanasan global mengakibatkan dampak yang luas dan serius bagi lingkungan bio-geofisik (seperti pelelehan es di kutub, kenaikan muka air laut, perluasan gurun pasir, peningkatan hujan dan banjir, perubahan iklim, punahnya flora dan fauna tertentu, migrasi fauna dan hama penyakit, dsb). Sedangkan dampak bagi aktivitas sosialekonomi masyarakat meliputi, gangguan terhadap fungsi kawasan pesisir dan kota pantai, gangguan terhadap fungsi prasarana dan sarana seperti jaringan jalan, pelabuhan dan bandara, gangguan terhadap permukiman penduduk, pengurangan produktivitas lahan pertanian, peningkatan resiko kanker dan wabah penyakit parasitik, dan sebagainya.

Pemanasan global sudah menjadi masalah yang harus kita hadapi atau kita pecahkan bersama. Marilah kita bersama-sama memulai dengan gaya hidup yang ramah lingkungan dimulai dari diri sendiri. Karena pada dasarnya yang menyebabkan terjadinya perubahan iklim (climate change) adalah manusia selain faktor alam juga. Hal kecil penyumbang pemanasan globalpun harus diperhatikan, salah satunya dengan pengurangan pemanfaatan energi fosil bumi dan perlindungan terhadap hutan harus tetap dilakukan. Oleh sebab itu, patut kita mengenali lebih jauh, apa yang dimaksud dengan pemanasan global, sehingga kita dapat berperan untuk menyikapi, bahkan dapat membantu menanggulanginya. 